\title{
HOW HAS THE COVID-19 PANDEMIC AFFECTED THE REAL AND MONETARY SECTORS IN INDONESIA?
}

\author{
Patria Yunita \\ University of Indonesia, Indonesia, patria.yunita@gmail.com/patria.yunita01@ui.ac.id
}

\begin{abstract}
This study aims to find empirical evidence for the effects of the Covid-19 pandemic on the Indonesia real and monetary sectors. The real sector condition is represented by fluctuations in the farmer exchange rate in ten provinces; this rate has direct and indirect effects on farmers' welfare. On the other hand, the condition of the monetary sector is illustrated by shifts in the consumer confidence index due to fluctuations in Islamic and conventional financial system indicators. We used a panel regression model to examine the farmer exchange rate and a binary logistic regression model to examine the consumer confidence index. The results statistically demonstrate that the pandemic conditions have affected both the real sector and the consumer confidence index of the Islamic financial sector. However, the pandemic has not affected the consumer confidence index of the conventional financial sector. This phenomenon exists because of the speculative action from conventional investors in taking risks and opportunities, which are forbidden in the Islamic context. The indicator which shifts the conventional consumer confidence index is the composite stock index (IHSG), while the Islamic consumer confidence index is shifted by changes in the Islamic money market rate, the Jakarta Islamic index and the Islamic banking capital ratio. Our empirical findings conclude that, in such a critical situation, the behaviour of conventional and Islamic consumers is totally different, thus influencing consumer confidence in each sector.
\end{abstract}

Keywords: Real sector, Monetary sector, Farmer, Consumer confidence index, Pandemic. JEL classification: E21; E32; E44.

Article history:

Received : October 6, 2020

Revised : March 1, 2021

Accepted : : March 13, 2021

Available online : March 31, 2021

https://doi.org/10.21098/jimf.v7i0.1361 


\section{INTRODUCTION}

\subsection{Background}

Several studies have concluded that the global financial crisis that occurred was the impact of decreased consumer confidence (Dees \& Brinca, 2013). Consumer behaviour is an integral part of long- and short-term macroeconomic policies. Juhro and Iyke (2019) state that consumption will shape the business cycle, so it affects short-term monetary policy. In addition, consumer decisions reflect the level of savings, interest rates, wage levels and long-term welfare, so affect longterm monetary and fiscal policy (Iyke \& Ho, 2019).

Juhro (2015) emphasises the importance of consumption as a driver of economic growth in emerging market such as Indonesia. The previous global financial crisis was predicted to be caused by consumption levels, because $60 \%$ of Indonesia's gross domestic product growth is determined by such levels (Juhro, 2015). The depth of the 2008-2009 financial crisis had an impact on the real economy, resulting from an erosion of consumer confidence (Dess \& Brinca, 2013). Therefore, an analysis of the stagnation in consumption is important in predicting the business cycle and the effectiveness of policy implementation. The consumer confidence index is an indicator of public optimism, as the driving factor for the economy (Juhro \& Iyke, 2019).

Consumer confidence is the central issue that changes the direction of consumption. Changes in consumption will affect business cycle fluctuations, reduce demand for goods and services and production output, reduce wage levels, and increase unemployment (Acemoglu \& Scoot, 1994). The consumer confidence index is a barometer of the economic health of a country from the consumers' perspective (Ferrer, Salaber, \& Zalewska, 2016). The index reflects consumers' degree of optimism in the general state of the economy and can be of value when forecasting economic conditions (Morlino \& Quaranta, 2016).

The index has significant implications for regulators when establishing strategic steps to increase market or public confidence. In essence, this is related to the credibility of monetary policy and the quality of the policies that are oriented towards the economy in the future. Throughout May 2015 to June 2020, there was a fall in the consumer confidence index in Indonesia, with a sudden change in December 2019 when the Covid-19 pandemic occurred internationally (see Figure 1). This event indicated a decline in public confidence in the Indonesian economy in the following 6 month period during the pandemic, related to business, salary levels and employment. 


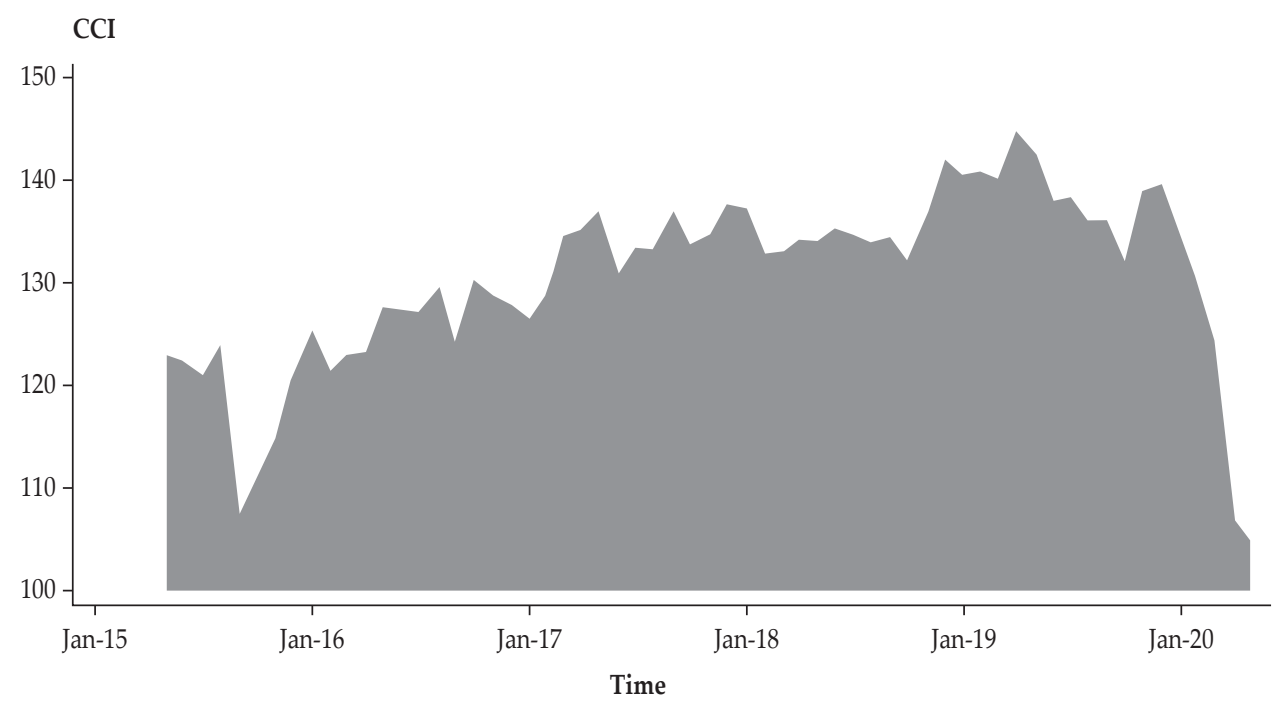

Source: Bank Indonesia (2020)

Figure 1.

Indonesia Consumer Confidence Index, May 2015-June 2020

The Covid-19 pandemic has affected the world in various ways (Mendez \& Alias, 2020). Together with the sudden change in the consumer confidence index, Central Bureau of Statistics data show an increase in the number of poor people in Indonesia due to the effects of the pandemic. From September 2019 to September 2020, poverty in Indonesia increased by $10.34 \%$, equivalent to 28.05 million peoples. From an analysis of the empirical data, at least $65 \%$ of Indonesians live by cultivating the land. This means that the majority of low income people in the country are farmers depending on farming activities. For this reason, we use the farmer exchange rate to indicate the fluctuation in low income transactions and the ability to produce food products in the real sector. Furthermore, from an Islamic economic perspective, people's consumption needs are daruriyyah, which must be fulfilled before hajiyyah and tahsiniyyah needs.

This study contributes by establishing empirical evidence for the effects of the pandemic on the Indonesian real and monetary sectors from both conventional and Islamic aspects. The real sector condition is described by the fluctuation in farmer exchange rates, which indicate the condition of the real sector in rural communities, sub-districts, districts and provinces. On the other hand, monetary sector conditions are illustrated by shifts in the consumer confidence index in terms of fluctuations in Islamic and conventional financial system indicators. Since Indonesia has adopted a dual monetary system, we developed two models: one of the Islamic financial sector, and the other of the conventional financial sector. Each model is represented by money market, stock market and banking indicators. The implications of our research will be useful for policymakers in forecasting economic developments and financial sector fluctuations, both from the Islamic and conventional perspectives. We used a panel regression model to analyse the 
real sector and a binary logistic regression model to analyse the monetary sector. Control variables were employed to ensure robust results.

\subsection{Research Objectives}

The study aims to find empirical evidence for the effects of the Covid-19 pandemic on the Indonesian real and monetary sectors, both from the conventional and Islamic perspectives. Our analysis used the farmer exchange rate as a variable to explain the conditions of the Indonesian real sector during the pandemic. Analysis of the fluctuations in the farmer exchange rate was conducted on ten provinces in Indonesia, namely Bangka Belitung, Banten, DI Yogyakarta, DKI Jakarta, West Java, Central Java, East Java, Nangroe Aceh Darussalam, Riau and North Sumatra. In addition, the condition of the monetary sector was illustrated by shifts in the consumer confidence index in terms of volatility in the Islamic and conventional financial system indicators.

Section 1 of the study outlines the background, while the remainder of the paper is structured as follows. Section 2 reviews the empirical literature on the farmer exchange rate and consumer confidence index. Section 3 describes the data and presents the empirical framework, while Section 4 presents the empirical findings. Finally, Section 5 presents the conclusion and policy recommendations.

\section{LITERATURE REVIEW}

Islam divides needs into three categories: daruriyah, hajiyyah and tahsiniyah. In pandemic conditions, foods security becomes important, and the majority of Indonesian live by cultivating the land. For this reason, we define low income welfare in pandemic conditions by the farmer exchange rate.

\subsection{Farmer Exchange Rate}

According to the Central Bureau of Statistics (2020), the farmer exchange rate is a proxy indicator for farmers' welfare. The rate is a comparison between the price index received by farmers (It) and the price index paid by farmers (Ib). A value higher than 100 means that farmers have a surplus. The production price increases more than the increase in the consumption price. Farmers' income rose more than their expenses. If the farmer exchange rate $=100$, this means that they break even. An increase or decrease in production prices is the same as the percentage increase or decrease in the price of consumer goods. Farmers' income is the same as their expenses. If the farmer exchange rate is lower than 100, it means that they have a deficit. The increase in production prices is relatively lower than the increase in prices for consumer goods. Farmers' income fell at a rate lower than their expenses.

The Central Bureau of Statistics explains that the use of farmer exchange rate analysis shows that the price index received by farmers (It) is an indicator of fluctuations in the price of goods produced by farmers. The index is used to support the calculation of income from the Indonesian agricultural sector. The price index of goods paid for by farmers $(\mathrm{Ib})$ is an indicator of fluctuations in the prices of consumed by farmers, who are in the majority in rural communities, as 
well as fluctuations in goods prices needed to produce agricultural products. The development of index $\mathrm{Ib}$ illustrates the development of inflation in rural areas.

The farmer exchange rate is also a measure of the ability for products to be exchanged by farmers for other products needed by them in production and household consumption. The rate shows the level of competitiveness of agricultural products compared to other products. On this basis, efforts to improve the quality of agricultural products can be made. Commodity coverage calculated the rate includes the food crops sub-sector, such as rice and secondary crops, and the subsectors of horticulture, smallholder crops, livestock and fisheries.

The methodology for determining farmer exchange rates is by conducting direct interviews using a list from the Central Bureau of Statistics. The sample is used in two stages, namely in each province and district, then the agricultural production centres are taken with the district market selection. Data regarding rates are calculated and presented on the website of the Central Bureau of Statistics, which is published monthly.

\subsection{Consumer Behaviour from Islamic and Conventional Perspectives}

The principle of consumption in Islamic economics has been developed based on the guidelines in the Quran and Sunnah. The principles form the moral framework for consumption and consumer behaviour. Kahf (1978), Khan (1984), Mannan (1986), Metwally (1997), Naqvi (1997), Zaman (1997), Siddiqi (2005) and Hasan (2005) proposed values to characterise Islamic consumer behaviour. Such behaviour in an Islamic framework is different from the conventional type. In the conventional concept, a consumer is perceived to behave rationally, whereas in the Islamic economic approach this behaviour is realistic and idealistic. Islamic consumer behaviour derived from the Quran and Sunnah set Islamic ethics, principles, guidance and direction in consumption action.

Based on the conventional viewpoint, according to the classical permanent income theory, the information available to consumers today has no effect on future consumption decisions (Hall, 1978). Based on this theory, consumption decisions are determined by current information and expectations of future income levels (Friedman, 1957). Such expectations are a fundamental factor in changes in the consumption level. From a theoretical viewpoint, the literature has focused on the conceptualisation of confidence and its role in modern theories of consumption. If consumers were to behave according to the permanent income hypothesis, no information known to them when a consumption choice was made could have any predictive power over how consumption would change in future periods (Hall, 1978). Fan and Wong (1998) state that the level of consumption increases if there is an increase in income. Based on the literature related to the animal spirit, aggregate economic activity is influenced by waves of pessimism and optimism. If consumers are optimistic about the future, they tend to postpone savings in order to consume more in the present.

According to the permanent income hypothesis, consumption patterns are determined by current and expected future income. Consumer will consume more if they expect their income to increase (Fan \& Wong, 1998). Juhro and Iyke (2019) argue that consumer and business sentiment plays an important role as a 
predictor of consumption expenditure. The sentiment and confidence index have very significant implications for Bank Indonesia in establishing strategic steps to enhance market or public sentiment. Basically, this is related to the credibility of monetary policy and the quality of policies that are oriented towards the economy in the future. Expectations about macroeconomic variables may influence the effectiveness of monetary and fiscal policy and the direction of the economy (Paradiso, Kumar, \& Margani, 2014).

\subsection{Consumer Confidence Index}

The consumer confidence index started in 1967 and is benchmarked to $1985=$ 100. This year was chosen because it was neither a peak nor a trough. The index is calculated each month on the basis of a household survey of consumers' opinions on current conditions and future expectations of the economy. Opinions on current conditions comprise $40 \%$ of the index, with expectations of future conditions constituting the remaining $60 \%$. The consumer confidence index is a monthly report detailing with consumer attitutes and buying intentions, with data available by age, income and region. The index has proven to be one of the most influential variables in consumption decisions and in the economic situation (Bock Eastman, \& McKay, 2014; Sorić, 2018). Consumer confidence is influenced by their personal finances and the economic environment, macroeconomic conditions and the business situation (Ferrer et al. 2016; Salhin, Sherif, \& Jones, 2016; Li, Guo, \& Park, 2017).

\subsection{Previous Studies}

We divided previous studies into two main topics: the farmer exchange rate and the consumer confidence index regarding the monetary sector. Research conducted by Setiyowati, Sasongko, \& Noor (2018) found that the farmer exchange rate is an indicator of farmers' welfare and can be a measurement of their real income (Setiyowati et al. 2018; Syekh, 2013). The Indonesian farmer exchange rate tended to increase from 2009 to 2013. The rate has direct and indirect effects on farmers' poverty. It can have a negative effect; if the rate increases, it will reduce the rate of farmer poverty (Setiyowati et al. 2018). In essence, the rate will be a driver for farmers' performance; a rising farmer exchange rate will improve farmers' prosperity (Syekh, 2013).

Many studies have investigated the relationship between the stock market and the consumer confidence index (Tobin, 1969; Bernanke, Gertler, \& Gilchrist, 1999; Poterba, 2000). The relationship can be explored in two ways. Some authors have found that stock market fluctuations contribute to changes in economic conditions. Stock prices are influenced by investor confidence. Some studies have investigated the opposite causal relation between stock prices and the consumer confidence index. The evolution of stock prices changes the consumer confidence index through the wealth effect (Bathia \& Bredin, 2013; Fisher \& Statman, 2003). Research conducted by Jansen and Nahuis (2003) found that the stock market confidence relationship is driven by expectations about economy-wide conditions, rather than personal finances. Chen (2011) argues that consumer confidence has 
asymmetric effects on stock returns. Reduced confidence pushes the stock market into bear territory. Market pessimism has a great impact on stock returns during bear markets.

A lack of consumer confidence leads to a higher probability of a switch to a bear market regime. Nadenicheck (2007) suggests that expectations should not be excluded as a possible source of economic difficulties. The consumer confidence index can be a good predictor of household consumption (Dees \& Brinca, 2013). Research conducted by Mendez and Alias (2020) found robust evidence that the Covid pandemic has increased herding behaviour in the capital markets of Europe. Three effects that can affect such behaviour are the asymmetric effects of market return, high and low volatility states, and domestic market trading volume (Tan, Chiang, Mason, \& Nelling, 2008; Mobarek, Mollah, \& Keasey, 2014).

Most academics and policymakers agree that it is the erosion of confidence that has ensured the depth and longevity of the crisis, especially as regards its impact on the real economy. Consumer confidence indices could be helpful, as they might capture information about expected income. From an empirical viewpoint, confidence indicators contain information beyond economic fundamentals; some focus on the special importance of confidence indicators in predicting periods of strong fluctuations in the economy, such as recessions and recoveries (Howrey, 2001; Haugh, 2005). During periods of major economic shock, usually associated with high volatility of consumer confidence, confidence could be useful as an indicator of consumption (Carroll, Fuhrer, \& Wilcox, 1994). Our empirical specifications are motivated by the theory mentioned earlier and empirical studies in consumer confidence shifted at financial crisis.

\section{METHODOLOGY}

\subsection{Data and Model Development of Real Sector Analysis}

\subsubsection{Data}

The data used to analyse the real sector were based on the farmer exchange rate as the dependent variable. The independent variables were regional inflation, regional economic growth, the number of Islamic rural bank offices, and dummy variables for the pandemic conditions. We used the farmer exchange rate as the dependent variable based on the consideration that in pandemic conditions the transaction of goods by those in the low income segment mostly concern primary foods. Moreover, most Indonesians live from farming and cultivating the land. In addition, regional inflation and regional economic growth are variables that influence the price of goods. We used Islamic rural banks on the assumption that in production activities farmers might need loans. In the study, to anticipate unobserved heterogeneity the model used the USD exchange rate and national economic growth as control variables. The data were taken from the regional economic monthly statistics of the Central Statistics Agency, Indonesian Banking Statistics, the Financial Services Authority and Indonesian Financial System Statistics, comprising panel data of ten provinces in Indonesia from January 2019 to February 2020. The variables of the real sector model are shown in Table 1. 
Table 1.

Variables in the Real Sector Model

\begin{tabular}{|c|c|c|c|}
\hline Variable & Proxy & Formula & Source \\
\hline $\begin{array}{l}\text { Dependent variable } \\
\text { Farmer exchange rates }\end{array}$ & FER & Farmer exchange rates & $\begin{array}{l}\text { Regional Economic } \\
\text { Statistics, Central } \\
\text { Bureau of Statistics }\end{array}$ \\
\hline $\begin{array}{l}\text { Independent variables } \\
\text { Regional inflation } \\
\text { Regional economic growth } \\
\text { Islamic rural banks } \\
\text { Pandemic dummy variable }\end{array}$ & $\begin{array}{c}\text { RINFR } \\
\text { RGDP } \\
\text { IRB } \\
\text { Pandemic }\end{array}$ & $\begin{array}{c}\text { RINF } \\
\text { RGDP } \\
\text { IRB } \\
\text { Pandemic }=1, \\
\text { No pandemic }=0\end{array}$ & $\begin{array}{c}\text { Regional Economic } \\
\text { Statistics, Central } \\
\text { Bureau of Statistics. } \\
\text { Indonesian Financial } \\
\text { Stability Study, Bank } \\
\text { Indonesia. } \\
\text { Indonesian Banking } \\
\text { Statistics, The Financial } \\
\text { Services Authority. }\end{array}$ \\
\hline $\begin{array}{l}\text { Control variable } \\
\text { USD exchange rate } \\
\text { National economic growth }\end{array}$ & $\begin{array}{l}\text { USD } \\
\text { GDP }\end{array}$ & $\begin{array}{l}\text { USD exchange rate } \\
\text { GDP }\end{array}$ & $\begin{array}{c}\text { Indonesian Financial } \\
\text { Stability Study, Bank } \\
\text { Indonesia }\end{array}$ \\
\hline
\end{tabular}

\subsubsection{Panel Data Model}

In this section, we briefly explain the model specification and method applied to analyse the Indonesian real sector during the pandemic. Following the panel data formula of Gujarati (2015), a panel random - fixed effect estimation model was employed, as shown below:

$$
\begin{aligned}
& F E R_{i . t}=\alpha_{1}+\beta_{1} R I N F_{i . t-1}+\beta_{2} R G D P_{i . t-1}+\beta_{3} I R B_{i . t}+ \\
& \beta_{4} \text { Dummy Pandemi } \\
& i . t+\beta_{5} U S D_{i . t}+\beta_{6} G D P+\varepsilon
\end{aligned}
$$

where:

$\begin{array}{ll}\text { FER } & : \text { Farmer exchange rate } \\ \text { RINF } & : \text { Regional inflation } \\ \text { RGDP } & : \text { Regional economic growth } \\ \text { IRB } & : \text { Islamic rural banks } \\ \text { Pandemic } & : \text { Pandemic }=1, \text { No pandemic }=0 \\ \text { USD } & : \text { USD exchange rate } \\ \text { GDP } & : \text { National economic growth }\end{array}$

\subsection{Data and Model Development of Monetary Sector Analysis}

\subsubsection{Data}

The data used to analyse the Indonesian monetary sector were the probability of consumer confidence index fluctuations, $Y=1$ and $Y=0 . Y=1$ is the probability of a falling consumer confidence index and $Y=0$ is the opposite. Electronic money transactions, the capital adequacy ratio of conventional banks, the capital adequacy ratio of Islamic banks, the Islamic money market rate, the conventional money market rate, the composite stock price index and the Jakarta IsIamic index 
were the independent variables. In the model we used the consumer confidence index as a dependent variable to predict Indonesian financial sector consumer confidence regrading the pandemic conditions. To analyse the Islamic financial sector, we used the Islamic money market rate, the Jakarta Islamic index and the Islamic banking capital ratio. These three variables represented the Islamic money market, the stock market and banking sector indicators. In addition, to analyse the conventional financial sector, we used the conventional money market rate, the Indonesian composite stock price index and the conventional bank capital ratio, which represented the conventional money market, stock market and banking sector. We also used electronic money transactions to analyse the conventional financial sector because in pandemic conditions conventional money market transactions rise sharply. To anticipate unobserved heterogeneity, the model employed the USD exchange rate, BI rate, national inflation rate, gold price and economic growth as control variables. The data were obtained from monthly statistics of the Indonesian Financial Stability, Gold Council and Indonesian Banking Statistics published monthly by Bank Indonesia and the Financial Services Authority in the research period May 2015 to June 2020.

Table 2.

Financial Sector Variables

\begin{tabular}{lccc}
\hline Variable & Proxy & Formula & Source \\
\hline $\begin{array}{l}\text { Dependent variable } \\
\text { Probability of consumer } \\
\text { confidence index fluctuations }\end{array}$ & PCCI & Consumer confidence index & $\begin{array}{c}\text { Indonesian Financial } \\
\text { Stability Study, Bank } \\
\text { Indonesia }\end{array}$ \\
$\mathrm{Y}=1$, if CCI $<1$. & & & \\
\hline Independent variables & & & \\
Electronic transactions & ET & Electronic money transactions & \\
Bank capital ratio & CAR & Capital adequacy ratio & Indonesian Financial \\
Islamic Bank capital ratio & CARIB & Capital adequacy ratio IB & Stability Study, Bank \\
Islamic money market rate & IMMR & Islamic money market rate & Indonesia. \\
Money market rate & MMR & Money market rate & The Financial \\
Islamic capital market index & JII & Jakarta Islamic index & Services Authority \\
Composite stock price index & CSPI & Composite stock price index & \\
\hline $\begin{array}{l}\text { Control variables } \\
\text { USD exchange rate }\end{array}$ & USD & USD exchange rate & Indonesian Financial \\
BI rate & BI & BI reference interest rate & Stability Study, Bank \\
Inflation rate & INF & Inflation & Indonesia \\
Gold price & Gold & Gold price & Gold Council \\
Economic growth & GDP & GDP &
\end{tabular}

\subsubsection{Logit Probit Estimation Model}

The data analysis in this study was made using the maximum likelihood logistic regression predictive model. By the dependent variable is the probability of consumer confidence index fluctuations, $\mathrm{Y}=1$ and $\mathrm{Y}=0$. 


\section{a. Logit Model}

Logit regression models are used to predict a dependent variable which is neither continuous nor binary.

$y=\left\{\begin{array}{l}1 \\ 0\end{array}\right.$ where 1 is the probability of a falling consumer confidence index and 0 otherwise.

The purpose of logistic regression is the same as linear regression, which is to analyse the relationship between the dependent and independent variable, but logistic regression does not use a linear relationship. The relationship between the dependent and independent variables is explained by the maximum likelihood curve. The logit equation model following Gujarati (2015) is as follows:

1. Model 1 (Islamic Financial Indicators)

$$
\begin{aligned}
& Y=\frac{O d d s_{i}}{1+O d d s_{i}} \\
& =\frac{e^{\beta+\beta_{1} I M M R+\beta_{2} J I I+\beta_{3} C A R I B+\beta_{4} G O L D+\beta_{5} G D P+\beta_{6} D u m m y \text { Pandemi }}}{1+e^{\beta+\beta_{1} I M M R+\beta_{2} J I I+\beta_{3} C A R I B+\beta_{4} G O L D+\beta_{5} G D P+\beta_{6} D u m m y \text { Pandemi }}} \\
& =\frac{1}{1+e^{-\left(\beta+\beta_{1} I M M R+\beta_{2} J I I+\beta_{3} C A R I B+\beta_{4} G O L D+\beta_{5} G D P+\beta_{6} \text { Dummy Pandemi }\right)}}
\end{aligned}
$$

where:

Y

IMMR : : Islamic money market rate

JII : Jakarta Islamic index

CARIB : Islamic bank capital adequacy ratio

GOLD : Gold price

GDP : Economic growth

Pandemic : Pandemic

$\beta \mathrm{k} \quad$ : Each coefficient of the independent variable

2. Model 2 (Conventional Financial Indicators)

$$
\begin{aligned}
& Y=\frac{O d d s_{i}}{1+O d d s_{i}} \\
& =\frac{e^{\beta+\beta_{1} M M R+\beta_{2} E T+\beta_{3} C S P I+\beta_{4} C A R+\beta_{5} \text { Dummy Pandemi }+\beta_{6} B I}}{1+e^{\beta+\beta_{1} M M R+\beta_{2} E T+\beta_{3} C S P I+\beta_{4} C A R+\beta_{5} \text { Dummy Pandemi }+\beta_{6} B I}} \\
& =\frac{1}{1+e^{-\left(\beta+\beta_{1} M M R+\beta_{2} E T+\beta_{3} C S P I+\beta_{4} C A R+\beta_{5} \text { Dummy Pandemi }+\beta_{6} B I\right)}}
\end{aligned}
$$

where:

Y

MMR

ET

CSPI
: Probability of consumer confidence index fluctuations

: Money market rate

: Electronic transaction

: Composite stock price index 
CAR : Capital adequacy ratio

Pandemic $\quad:$ Pandemic $=1$, No pandemic $=0$

BI : Bank Indonesia certificate rate

$\beta \mathrm{k} \quad$ : Each coefficient of the independent variable

\section{b. Probit Model}

A probit model is an alternative to the logit method. The main difference is that in the probit model a normal distribution of the random variable (the independent variable in the model) is assumed. The $Y$ value is the $Z$ value of the normal distribution. The higher the $Y$ value, the more likely the probability that $Y=1$ will occur. The probability regression model of probability $\mathrm{Y}=1$ uses the cumulative standard normal distribution function, $\Phi(\mathrm{z}) . \Phi$ is the cumulative standard normal distribution function and $z=\beta 0+\beta 1 X$ is the " $z$-value" or "z-index" of the model. The probit regression model in this study is as follows:

1. Model 1

$$
\operatorname{Pr}(Y=1 \mid X)=\Phi\left(\beta+\beta_{1} I M M R+\beta_{2} J I I+\beta_{3} C A R I B+\beta_{4} G O L D+\beta_{5} G D P+\right.
$$
$\beta_{6}$ Dummy Pandemi)

Marginal Effect Probit Regression

$$
\begin{aligned}
& Y=\Phi\left(\beta+\beta_{1} I M M R+\beta_{2} J I I+\beta_{3} C A R I B+\beta_{4} G O L D+\beta_{5} G D P+\right. \\
& \left.\beta_{6} \text { Dummy Pandemi }\right)
\end{aligned}
$$

Therefore,

$$
\begin{aligned}
& \frac{\partial Y}{\partial X_{i}}=\beta_{i} \Phi\left(\beta+\beta_{1} I M M R+\beta_{2} J I I+\beta_{3} C A R I B+\beta_{4} G O L D+\beta_{5} G D P+\right. \\
& \left.\beta_{6} \text { Dummy Pandemi }\right)
\end{aligned}
$$

2. Model 2

$$
\begin{aligned}
& \operatorname{Pr}(Y=1 \mid X)=\Phi\left(\beta+\beta_{1} M M R+\beta_{2} E T+\beta_{3} C S P I+\beta_{4} C A R+\right. \\
& \left.\beta_{5} \text { Dummy Pandemi }+\beta_{6} B I\right)
\end{aligned}
$$

Marginal Effect Probit Regression

$$
\begin{aligned}
& Y=\Phi\left(\beta+\beta_{1} M M R+\beta_{2} E T+\beta_{3} C S P I+\beta_{4} C A R+\right. \\
& \left.\beta_{5} \text { Dummy Pandemi }+\beta_{6} B I\right)
\end{aligned}
$$

Therefore,

$$
\begin{aligned}
& \frac{\partial Y}{\partial X_{i}}=\beta_{i} \Phi\left(\beta+\beta_{1} M M R+\beta_{2} E T+\beta_{3} C S P I+\beta_{4} C A R+\right. \\
& \left.\beta_{5} \text { Dummy Pandemi }+\beta_{6} B I\right)
\end{aligned}
$$




\section{c. Model Selection}

The choice between logit or probit models is made using standard information such as the Akaike Information Criteria (AIC) or the Bayesian Information Criterion (BIC). In this study, we compared the prediction accuracy of the model using AIC and BIC. AIC provides an effective tool for model selection (Clements et al., 2015; Dimitriou et al., 2013). The number of parameters in the model is the log likelihood function. The model chosen is one with minimum BIC and AIC values.

Logistic regression does not have an R-squared as in OLS regression. Count R2 measures the correctly predicted fraction if the $\mathrm{Y}$ fraction's prediction probability is $>50 \%$ when $\mathrm{Yi}=1$ or $<50 \%$ when $\mathrm{Yi}=0$. In logistic regression, pseudo $\mathrm{R} 2$ is used, which equals Model L2 / -2LLo. -2Llo measures the increase in the relative $\log$ value if it has no independent variables. Parameter estimation for fit models uses maximum likelihood estimation (MLE), which describes the best distribution of the data studied. Prob> chi2 is used to obtain the chi-square statistic for the null hypothesis.

\subsection{Structural Break Analysis}

Structural breaks occur in time series or cross-sectional data, when there is a sudden change in the variable being studied. Studies on structural breaks began with the work of Chow in 1960 (Muthuramu \& Maheswari, 2019). They can be organised in the structure of the economy and on-going policies, specially in their timing, trend, change point and date shifts. Our analysis used the Wald test to detect the occurrence of structural breaks in the studied variables.

Sample period: $t=1, \ldots ., n$

Breakdate: T1 (change date)

Pre-rest sample: $\mathrm{t}=1, \ldots$. observations $\mathrm{T} 1$ or $\mathrm{T} 1$

Post-rest sample: $\mathrm{t}=\mathrm{T} 1+1, \ldots ., \mathrm{n}$; observation $\mathrm{n}$ - T1

Wald Test Statistics, (Hansen, 2012)

$$
W\left(T_{1}\right)=n\left(\beta_{1}^{\prime}-\beta_{2}\right)\left(V_{1} \frac{n}{T_{1}}+V_{2} \frac{n}{n-T_{1}}\right)^{-1}\left(\beta_{1}^{\prime}-\beta_{2}\right)
$$

\subsection{Method}

The study aims to find empirical evidence for the effects of the Covid-19 pandemic on Indonesian real and monetary sectors. The real sector condition is described by fluctuation in the farmer exchange rates in ten provinces in Indonesia. The rate has direct and indirect effects on farmer poverty. On the other hand, the condition of the monetary sector is illustrated by shifts in the consumer confidence index due to fluctuations in financial system stability. In examining the fluctuations in the farmer exchange rate in the real sector, panel regression robustness standard error was used. The research scheme is shown in Figure 2. 


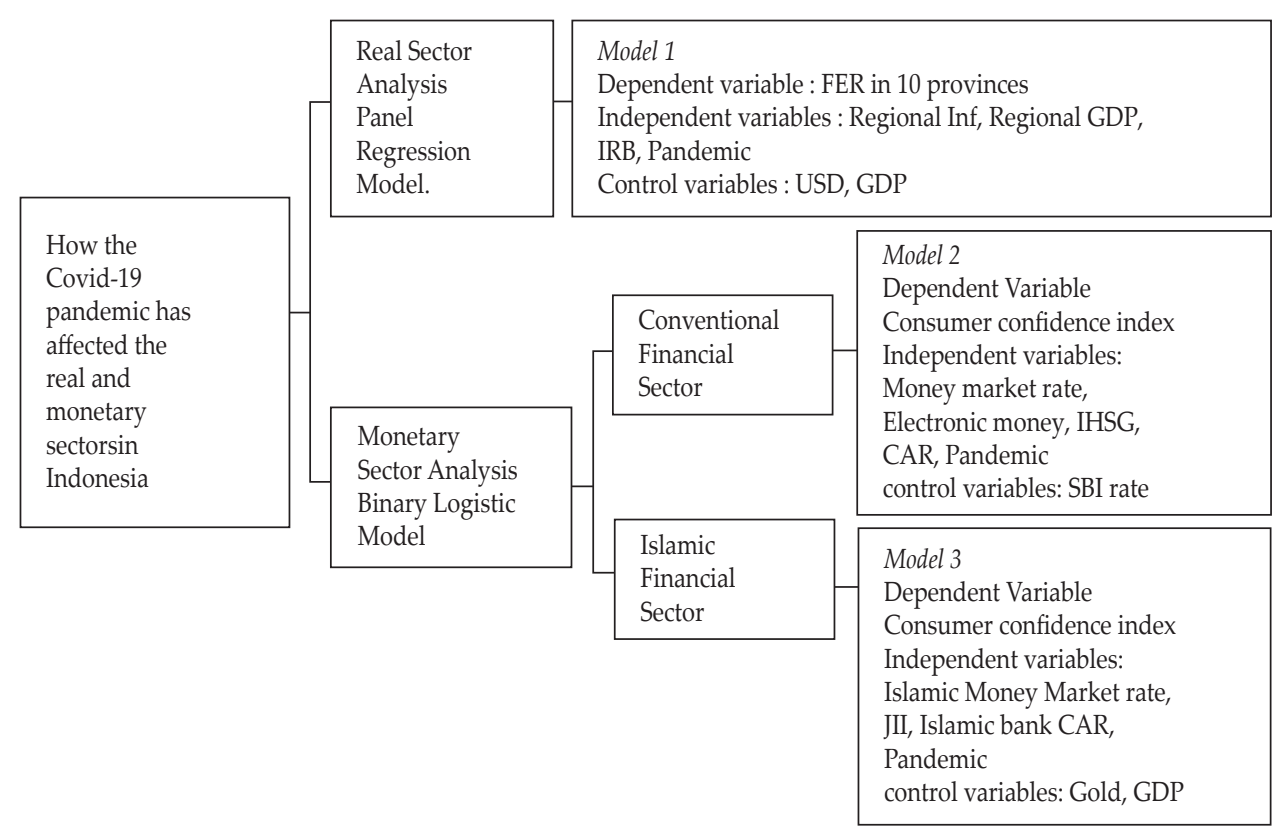

Figure 2.

Research Scheme

To examine the fluctuations in the consumer confidence index in the financial sector, binary logistic regression robustness standard error was used.

Gujarati (2015) states that panel models pose several estimations; the two most prominently used being the fixed effects model (FEM) and random effects model (REM). Gujarati suggests that the Hausman test can be used to decide between FEM and REM. Beside this test, in this study we also used the Breusch Pagan Lagrange Multiple test to decide between pooled ordinary least squared (POLS) and random effects models. Structural break analysis was also employed to describe the fluctuation in all the variables in the period observed. This will explain the resistance of variables in critical situations.

\section{RESULTS AND ANALYSIS}

\subsection{RESULTS}

4.1.1 Analysis of the Indonesian Real Sector During the Pandemic a. Descriptive Statistics of the Dependent-Independent Variables

Descriptive statistics of the dependent, independent and control variables of the Indonesian real sector during the pandemic are shown in Table 3. 
Table 3.

Descriptive Statistics of the Dependent - Independent Variables

\begin{tabular}{lccccc}
\hline Variable & Obs & Mean & Std. Dev & Min & Max \\
\hline Farmer exchange rates & 140 & 91.71 & 31.06 & 0.00 & 123.93 \\
Regional inflation & 140 & 2.44 & 1.07 & -0.90 & 4.02 \\
Regional GDP & 140 & 4.85 & 1.30 & -0.17 & 7.51 \\
Islamic rural banks & 140 & 9.86 & 9.33 & 1.00 & 28.00 \\
Pandemic dummy & 140 & 0.29 & 0.45 & 0.00 & 1.00 \\
USD & 140 & 14104.50 & 170.99 & 13662.00 & 14385.00 \\
GDP & 140 & 4.73 & 0.72 & 2.97 & 5.87 \\
\hline
\end{tabular}

We calculated the variables of farmer exchange rate, regional inflation, regional GDP, Islamic rural banks and national GDP in percentages. The pandemic dummy is a dummy variable representing the pandemic conditions. The USD variable is the USD exchange rate calculated by nominal.

\section{b. Correlation of Real Sector Variables}

The statistics for the correlation between the variables are given in Table 4 . Correlation analysis was performed to identify the directional strength of the relationship between the dependent and independent variables.

Table 4.

Correlation Between Dependent - Independent Variables

\begin{tabular}{lcccccc}
\hline Obs $=$ 140 & FER & INFR & PDBR & IRB & USD & GDP \\
\hline FER & 1.0000 & & & & & \\
INFR & -0.2692 & 1.0000 & & & & \\
PDBR & -0.2378 & 0.3857 & 1.0000 & & & \\
IRB & 0.3082 & 0.3041 & 0.0437 & 1.0000 & & \\
USD & -0.0361 & 0.0640 & 0.2043 & 0.0028 & 1.0000 & \\
GDP & -0.0573 & 0.0570 & 0.5864 & 0.0030 & 0.3913 & 1.0000 \\
\hline
\end{tabular}

The correlation analysis helped to establish whether there was a multicollinearity problem among the independent variables. Multicollinearity is a problem in regression models in which there is a relationship between the independent variables (general correlation scores are above 0.8). From the data presented in Table 4, it can be seen that there is no multicollinearity in any of the variables observed. Therefore, we assume that the estimation model developed is suitable for accurately predicting the relationship between the dependent and independent variables.

Based on the correlation test results shown in Table 4, the farmer exchange rate in the ten provinces observed had a positive correlation with the existence of Islamic and conventional rural banks. This means that the existence of Islamic rural banks indicates the possibility of an increasing farmer exchange rate resulting from the financing provided. In addition, the rate has a negative correlation with regional inflation, regional economic growth, the dollar exchange rate and 
national economic growth. To analyse the changes in the farmer exchange rates in the ten provinces, panel regression model robustness standard error was used. The statistical results of the panel data estimation are reported in Table 5.

Table 5.

POLS and Panel Regession Robustness SE Model 1 - Real Sector Analysis

\begin{tabular}{lccc}
\hline $\begin{array}{l}\text { Dependent variable: } \\
\text { Farmer Exchange Rates }\end{array}$ & $\begin{array}{c}\text { Pooled Ordinary } \\
\text { Least Squared } \\
\text { (POLS) }\end{array}$ & $\begin{array}{c}\text { Random Effect } \\
\text { Model } \\
\text { (REM) }\end{array}$ & $\begin{array}{c}\text { Fixed Effect } \\
\text { Model } \\
\text { (FEM) }\end{array}$ \\
\hline Independent variable & & & \\
\hline RINF & $-9.83836^{* * *}$ & -0.5767847 & -0.5564761 \\
RGDP & $-3.804719^{* *}$ & $1.240275^{* * *}$ & $1.258388^{* * *}$ \\
IRB & $1.390892^{* * *}$ & 1.094001 & 1.210103 \\
USD & 0.0014735 & -0.0013085 & -0.0013199 \\
GDP & 3.634622 & $-2.849873^{* * *}$ & $-2.87217^{* * *}$ \\
Pandemic dummy & 3.476459 & $1.876189^{* * *}$ & $1.881439^{* * *}$ \\
-Cons & 81.46731 & $107.7263^{* * *}$ & $106.629^{* * *}$ \\
Number of observations & 140 & 140 & 140 \\
Number of groups & - & 10 & 10 \\
Prob> Chi2 & 0.0008 & 0.0000 & 0.0000 \\
R-sq within & - & 0.4318 & 0.4318 \\
R-sq between & - & 0.0863 & 0.0863 \\
R-sq overall & 0.2555 & 0.0901 & 0.0901 \\
\hline Note: ***, ${ }^{* * *}$ denote statistical significance at the levels of 0.10, $0.05,0.01$ respectively. LPM uses Prob> F and \\
R-squared. & & &
\end{tabular}

After analysing the panel data in the ten provinces in the periods before and during the pandemic, we used the Breusch-Pagan Lagrange Multiple Test (BPLM) to choose between POLS and REM. From this test Prob $>$ chibar2 $=0.0000$ decision significant rejected to use POLS, so our conclusion was to use the REM model. POLS and REM are almost the same regression models; the difference is the error between observations within groups is controlled in the REM. After the BreuschPagan Lagrange Multiple Test, the Hausman test was conducted to select the better of the REM and FEM models (Gujarati, 2015). The resulkt obtained was a Prob > chi2 value of 0.9995 , so the analysis was performed using the random effects model. Based on the results of the random effects regression model, it can be concluded that the pandemic conditions are statistically significant, affecting the changes in the farmer exchange rates in the ten provinces. This means that there was a difference in the rate before and after the pandemic broke out internationally.

The farmer exchange rate is one indicator to determine the level of farmer welfare, so can be a measurement of farmers' real income (Setiyowati et al. 2018; Syekh, 2013). Figure 3 shows that the farmer exchange rate after the pandemic broke out is higher than before. It can be seen that the average farmer exchange rate has increased during the pandemic. This could have occurred due to the subsidies provided by the government to the poor during pandemic, which was one of the Indonesian government's policies to increase the consumption of lowincome people. 


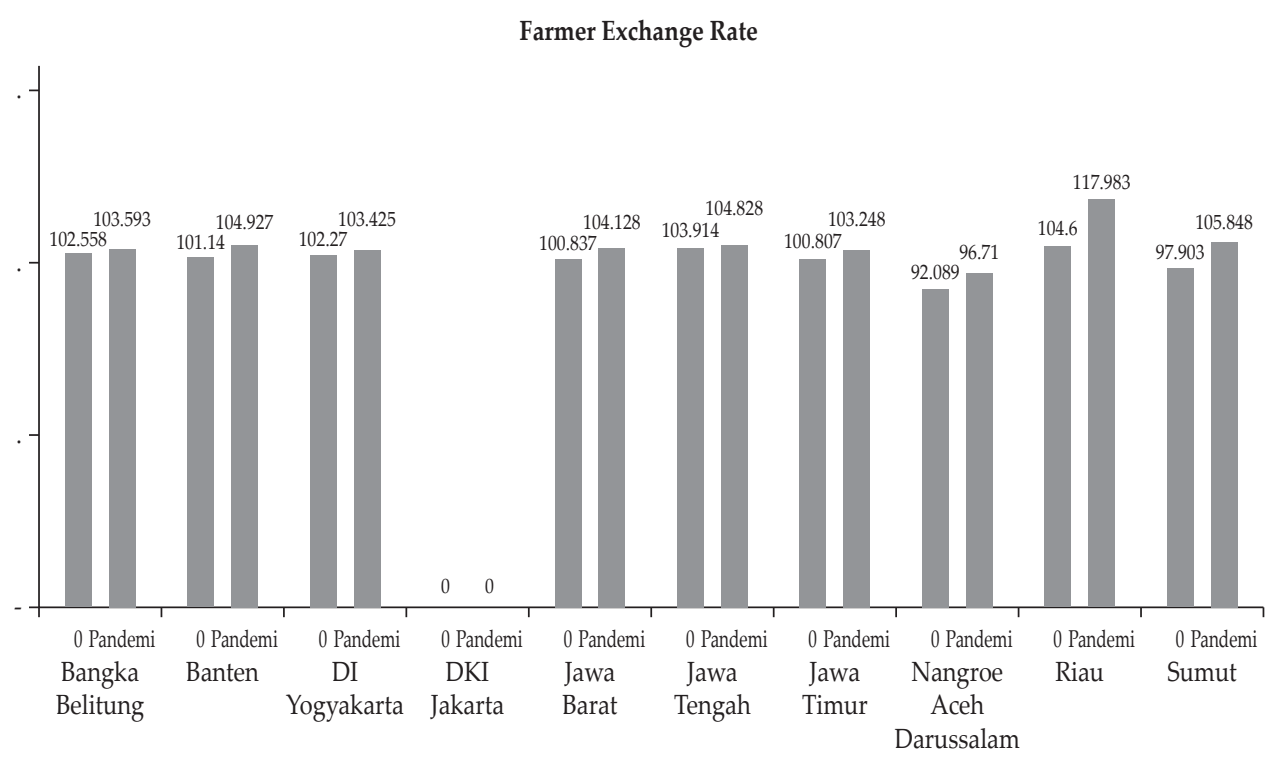

Source: Central Statistics Bureau (2020).

Figure 3.

Farmer Exchange Rates in the Ten Provinces Before and During the Pandemic

The farmer exchange rate has a direct negative effect on poverty; if it increases, it will reduce the rate of farmer poverty (Setiyowati et al. 2018). In essence, the will be a driver for farmers' performance, so an increased rate will improve farmers' prosperity (Syekh, 2013). Our analysis of the ten provinces concluded that the highest farmer exchange rate was in Riau, and the lowest in Nangro Aceh Darussalam. The rate in DKI Jakarta is zero because it is a major industrial city, the centre of government. We included it to analyse the effects of the pandemic in the provinces based on business and agricultural sectors.

The average rate in the ten provinces before and during the pandemic is $>$ 100. This means that the increase in production prices after the outbreak of the pandemic has been greater than the increase in farmers' consumption prices. The income of farmers at the village, sub-district, regency and provincial levels has increased more than their expenditure. The increase in production prices is relatively lower than those for consumer goods. Apart from the effects of the pandemic, fluctuations in the farmer exchange rates are also indicated by changes in regional gross domestic product and economic growth at the national level. 


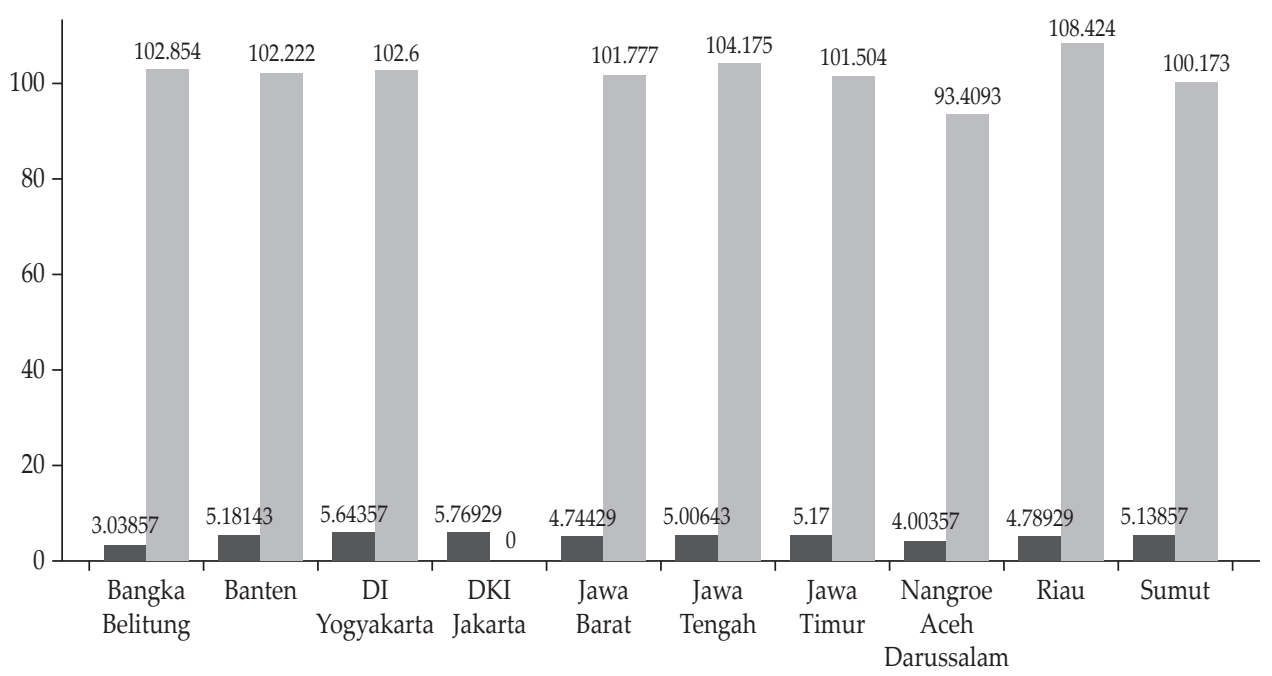

Mean Regional Economic Growth Mean Farmer Exchange Rate

Source: Central Statistics Bureau (20200.

Figure 4.

Farmer Exchange Rates in the Ten Provinces in Indonesia

\subsubsection{Analysis of the Indonesian Monetary Sector During the Pandemic}

\section{a. Descriptive Statistics of the Dependent Variables}

Analysis of consumer confidence in the Indonesian monetary sector during the pandemic was made using the binary logistic regression model. The descriptive statistics of the consumer confidence index fluctuations are shown in Table 6.

Table 6.

Probability of Consumer Confidence Index Fluctuations

\begin{tabular}{lccc}
\hline CCI & Freq. & Percent & Cumulative \\
\hline $\mathrm{Y}=1$, Decreasing CCI & 25 & 48.98 & 48.98 \\
$\mathrm{Y}=$ 0, Increasing CCI & 36 & 59.02 & 100.00 \\
Total & 61 & 100 & - \\
\hline
\end{tabular}

From the results of the binary logistic model, the probability of falls in the consumer confidence index $(Y=1)$ in the period May 2015 - June 2020 occurred 25 times, while the probability of increases in the index $(Y=0)$ occurred 36 times. This means that the probability of decreases in the consumer confidence index was $48.98 \%$ or lower than index increases. This means that the Indonesian economy during the period in question was quite strong with reference to the economic actors in general. 


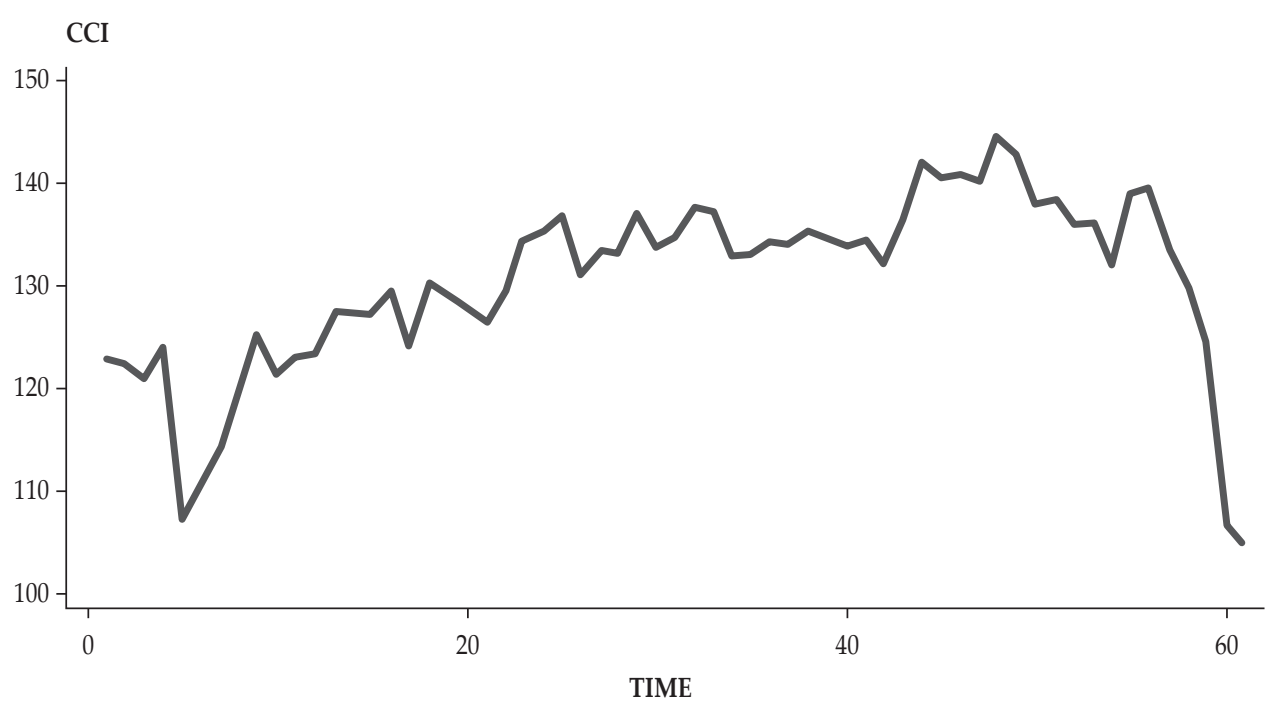

(a) Sharp fall in Dec. 2019

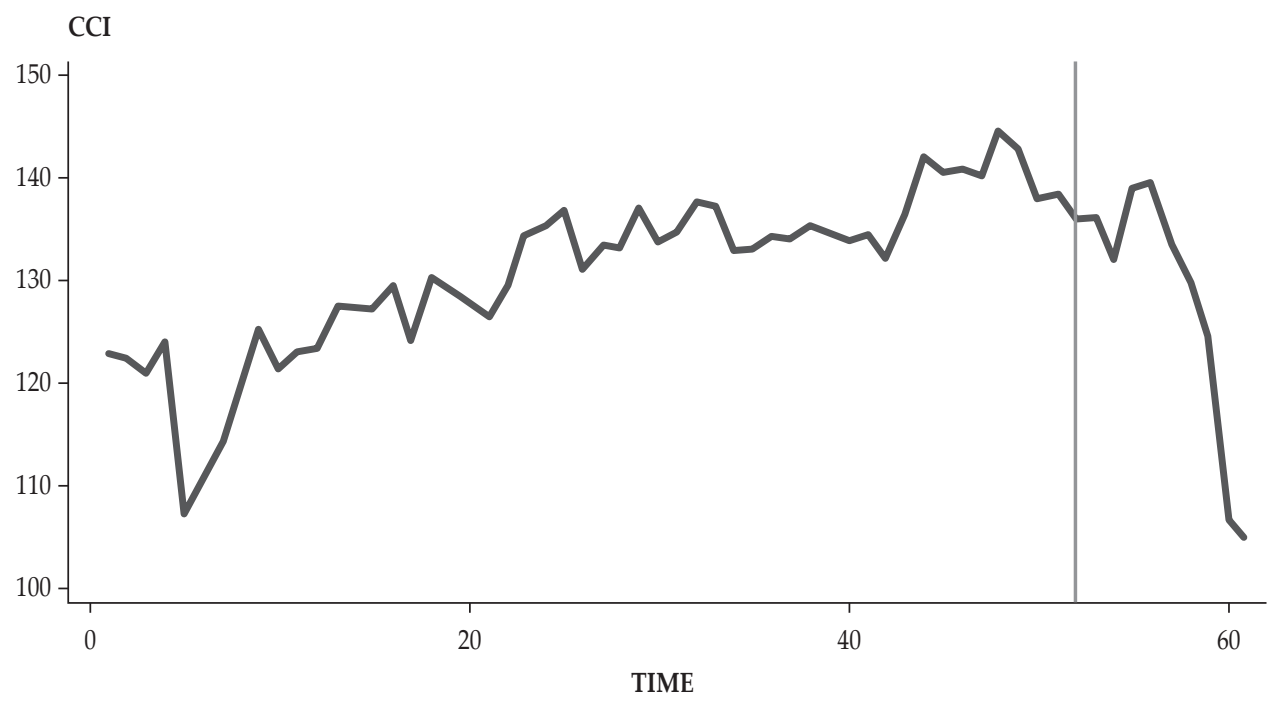

(b) Structural Break in Aug. 2019

Source: Bank Indonesia (2020).

\section{Figure 5}

Indonesian Consumer Confidence Index May 2015 - June 2020

However, based on Figure 5, there was a sudden change of in the consumer confidence index in December 2019 when the Covid-19 pandemic broke out in Indonesia. It can be seen in the figure that the index underwent a sudden change in August 2019 when it increased slightly before falling sharply in December 2019. 


\section{b. Descriptive Statistics: Independent Variables}

The descriptive statistics of the independent and control variables are shown in Table 7.

Table 7.

Descriptive Statistics of the Independent Variables

\begin{tabular}{lccccc}
\hline Variable & Obs & Mean & Std. Dev & Min & Max \\
\hline IMMR & 61 & 4.35 & 0.98 & 1.84 & 6.33 \\
MMR & 61 & 5.90 & 0.99 & 3.20 & 7.92 \\
ET & 61 & 560560.50 & 82005.62 & 427271.30 & 774207.20 \\
JII & 61 & 675.69 & 62.09 & 476.39 & 787.12 \\
ICPI & & & & & \\
CARIB & 61 & 17.78 & 2.37 & 14.09 & 21.39 \\
CAR & 61 & 22.62 & 0.86 & 20.28 & 23.93 \\
INF & 61 & 3.71 & 1.21 & 1.96 & 7.26 \\
BI & 61 & 5.55 & 1.09 & 4.25 & 7.50 \\
USD & 61 & 13856.43 & 611.75 & 12998.00 & 16310.00 \\
GOLD & 61 & 1298.62 & 139.34 & 11068.30 & 1716.40 \\
GDP & 61 & 5.67 & 0.96 & 2.97 & 6.90 \\
\hline
\end{tabular}

The Islamic money market rate, conventional money market rate, Jakarta Islamic index, Islamic banking capital, conventional banking capital, inflation rate, SBI rate and economic growth variables are counted in percentages, while electronic transactions, USD exchange rate and gold prices are counted by nominal.

\section{c. Correlation Between Monetary Sector Variables}

The correlation statistics between variables are illustrated in Table 8. Correlation analysis between dependent and independent variable was carried out to identify the directional strength among variables.

Table 8.

Correlation Between the Dependent and Independent Variables

\begin{tabular}{lccccccc}
\hline Obs $=$ 61 & Y & IMMR & MMR & ET & JII & CARIB & CAR \\
\hline Y & 1,0000 & & & & & & \\
IMMR & 0.2742 & 1,0000 & & & & & \\
MMR & 0.2754 & 0.6863 & 1,0000 & & & & \\
ET & 0.6824 & 0.1145 & 0.3081 & 1,0000 & & & \\
JII & 0.6362 & 0.1437 & 0.0426 & 0.1221 & 1,0000 & & \\
CARIB & 0.4605 & 0.0313 & 0.2454 & 0.8425 & -0.1145 & 1,0000 & \\
CAR & 0.6757 & 0.0823 & 0.1999 & 0.6089 & 0.6089 & 0.4668 & 1,0000 \\
\hline Obs = 61 & INF & GOLD & SBI & USD & GDP & & \\
\hline INF & 1,0000 & & & & & & \\
GOLD & -0.5352 & 1,0000 & & & & & \\
BI & 0.6106 & -5259 & 1,0000 & & & & \\
USD & -0.2575 & 0.3545 & -0.0322 & 1,0000 & & & \\
GDP & -0.3776 & -0.1606 & -0.5162 & -0.2246 & 1,0000 & & \\
\hline
\end{tabular}


From the data presented in Table 8, it can be seen that in general there is no multicollinearity among the variables. It can be assumed that the logistic regression created by the model is good enough to be used as a tool to predict the consumer confidence index fluctuations during the pandemic. Based on the correlation test, the index has a positive correlation with IMMR, MMR, ET, JII, CARIB, CAR, SBI and a negative one with gold prices, USD and GDP.

\section{d. Probit Logit Model Robustness Standard Error}

In predicting the probability of consumer confidence index fluctuations during the pandemic, regression analysis was performed using a linear probability model (LPM) by significance $\alpha=5 \%$. The results of the LPM model analysis show a patterned residual in which there are values of $Y$ hat $<0$ (lower than 1) and $Y$ hat $>1$ (higher than 1 ), so the predictions were made using the probit logit regression model. Several independent variables can increase the expectations of economic actors regarding changes in the pandemic condition, as shown in the probit logit analysis. Regarding the structural break analysis, the Indonesian consumer confidence index experienced a sudden change in December 2019, when the pandemic broke out internationally. From the Stata application, the logistic regression model results are shown in Table 9. To analyse the movement of the consumer confidence index, we divided the analysis into two separate models: Islamic financial sector indicators and conventional financial sector indicators.

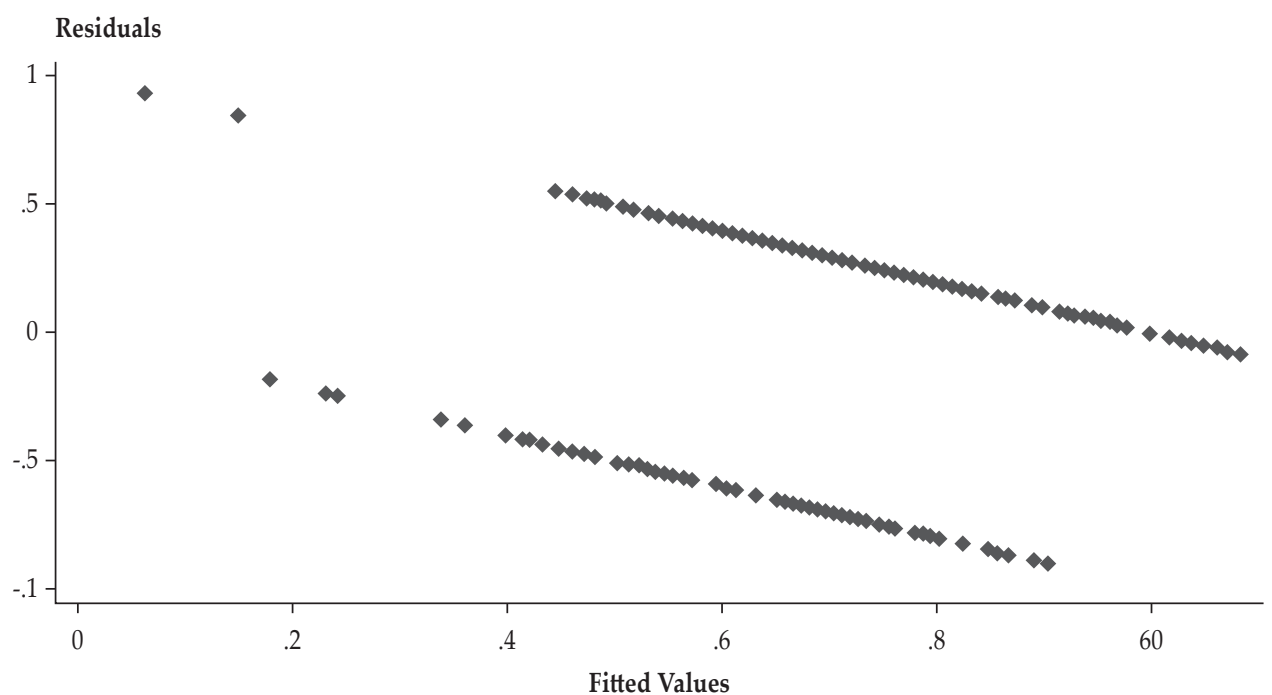

Source: Processing of statistical data

Figure 6.

Residual and Y Hat Linear Probability Model (LPM) 
The consumer confidence index has been proven to be one of the most influential variables in consumption decisions and in the economic situation (Bock et al.; 2014; Sorić, 2018). From logistic regression model results shown in Table 9, it can be concluded that statistically the JII index, Islamic bank capital, gold price, economic growth and USD exchange rate have negatively and significantly affected the changes of in the consumer confidence index.

Table 9.

LPM and Probit Logit Regression Robustness SE Model 1 Probability of Consumer Confidence Index Fluctuations - Islamic Financial Sector

\begin{tabular}{lccc}
\hline $\begin{array}{l}\text { Dependent Variable } \\
\begin{array}{l}\text { Probability of consumer confidence } \\
\text { index fluctuations }\end{array}\end{array}$ & LPM & $\begin{array}{c}\text { Logit } \\
\text { Model }\end{array}$ & $\begin{array}{c}\text { Probit } \\
\text { Model }\end{array}$ \\
\hline Independent variables & & & \\
\hline IMMR & 0.0079973 & 3.011558 & 1.568359 \\
JII & $-0.0035249^{* * *}$ & $-0.1352685^{* *}$ & $-0.0751795^{* * *}$ \\
CARIB & $-0.1690758^{* * *}$ & $-5.434795^{* * *}$ & $-3.024617^{* * *}$ \\
GOLD & 0.0005751 & $-0.0341063^{* * *}$ & -0.0204633 \\
GDP & -0.0367824 & -3.257818 & -2.128219 \\
Pandemic dummy & 0.0862704 & $13,96018^{* * *}$ & $7.474597^{* * *}$ \\
Cons & 5.246829 & $239.1985^{* * *}$ & $137.5179^{* * *}$ \\
Number of observations & 61 & 61 & 61 \\
Wald chi2 (6) & - & 17.45 & 19.03 \\
Prob> Chi2 & 0.0000 & 0.0078 & 0.0041 \\
Pseudo R-squared & 0.7295 & 0.8818 & 0.8812 \\
Log likelihood & - & -4.9485266 & -4.9770619 \\
Predicted & - & $98.36 \%$ & $98.36 \%$ \\
Sensitivity & - & $96.30 \%$ & $96.30 \%$ \\
Specificity & & $100 \%$ & $10 \%^{*} \%$ \\
\hline N & & & \\
\hline
\end{tabular}

Note: ${ }^{*}{ }^{* *},{ }^{* * *}$ denote statistical significance at the levels of $0.10,0.05,0.01$ respectively. LPM uses Prob> F and R-squared.

This means that increase in JII, Islamic bank capital, gold prices and economic growth strengthens the consumer confidence index, especially regarding consumers of Islamic finance products. From the logit model, the pandemic situation is significantly influencing the changes in investor confidence in the Islamic financial market. Consumer confidence is influenced by their personal finances, economic environment, macroeconomic condition and business situation (Ferrer et al., 2016; Salhin et al., 2016; Li et al., 2017).

There are many factors that affect Islamic consumer behaviour. There are certain prohibitions that guide such behaviour, one of which is gharar, or uncertainty. Gharar is interpreted as inadequate market information or uncertainty about exchange objects when there are no practical obstacles to obtaining full information. In Islamic finance, a market is subject to shariah constraints, meaning the market must be free from prohibited activities and elements such as riba (usury), maisir (gambling), and gharar (uncertainty). The pandemic situation has 
brought uncertainty in many ways, especially in the financial sector. Hoffman and Fieseler (2012) explained that investor perceptions fluctuated significantly during the crisis, with risk tolerance and risk perceptions being less volatile than return expectations. During the worst month of the crisis, investors' return expectations and risk tolerance fell, while their risk perceptions rose.

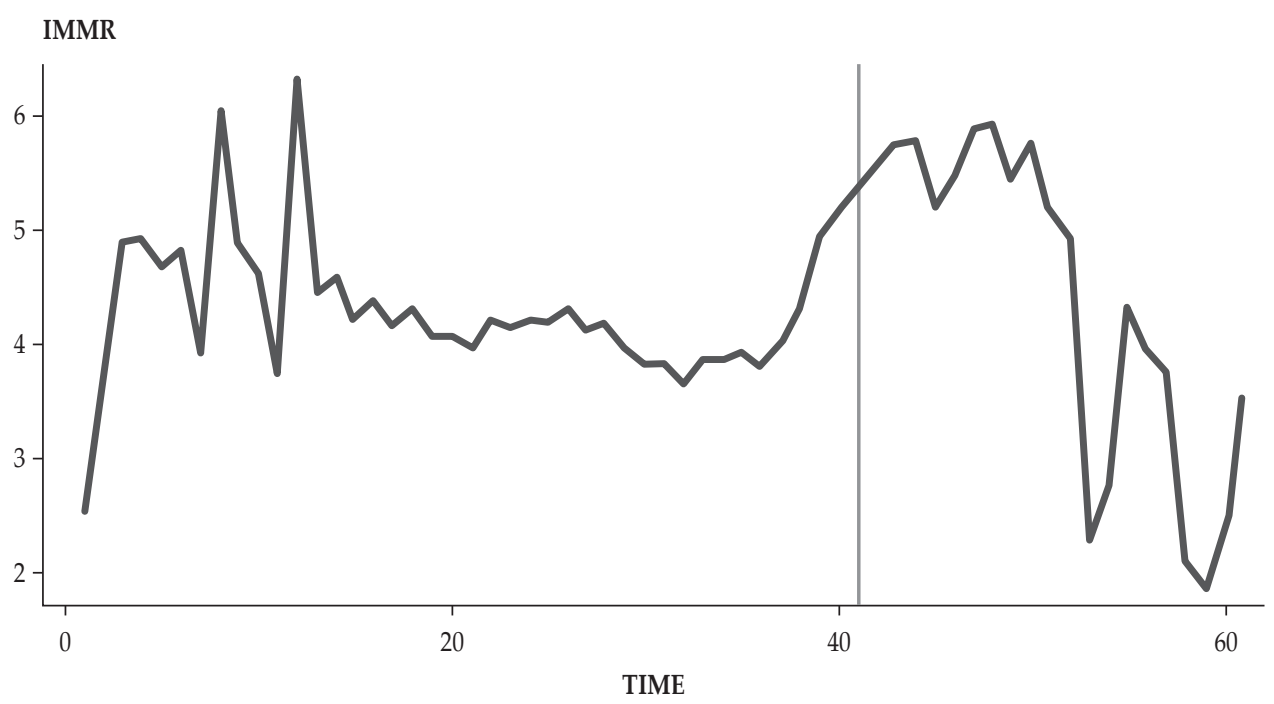

IMMR Break September 2018

Figure 7. Islamic MMarket ON Rate

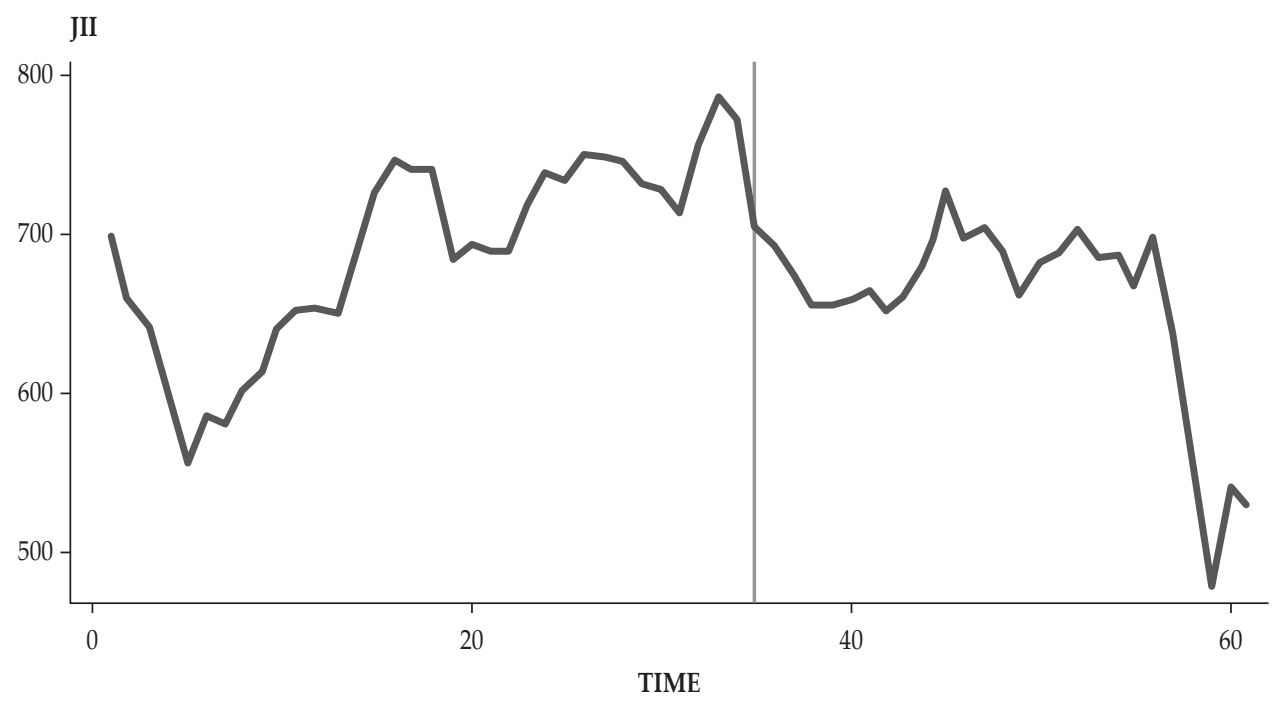

JII Break March 2018

Figure 8. Jakarta Islamic Index 


\section{CAR IB}

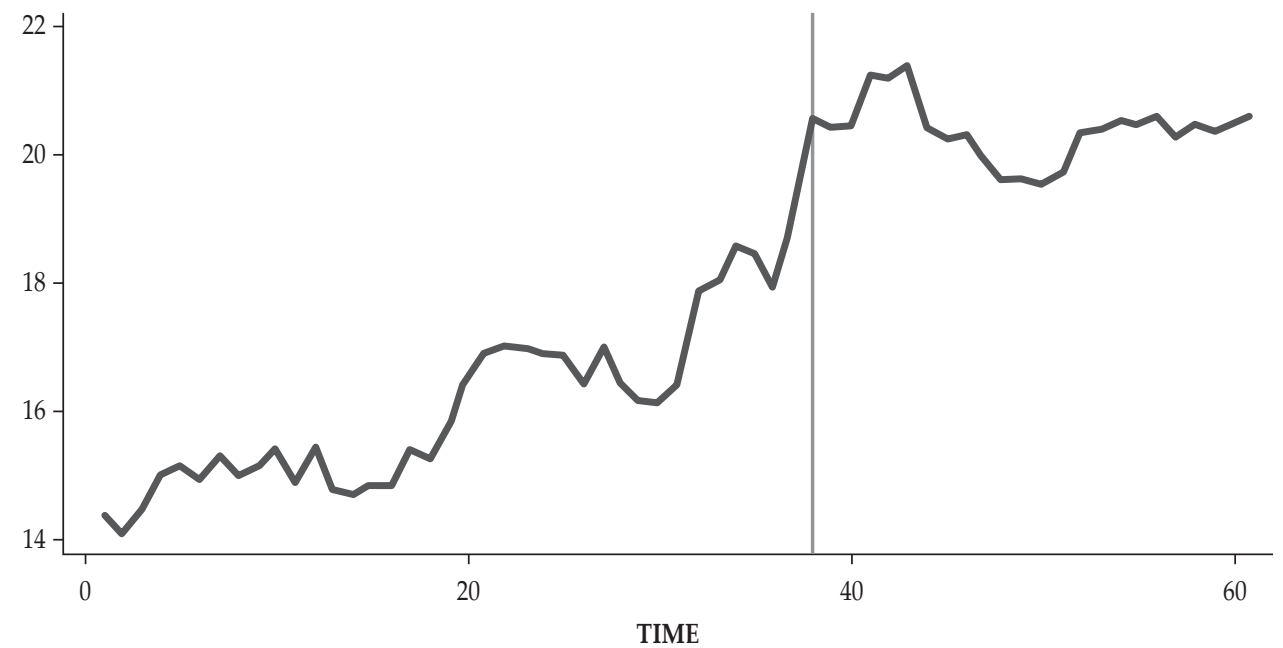

Break June 2018

Figure 9. Islamic Bank-CAR

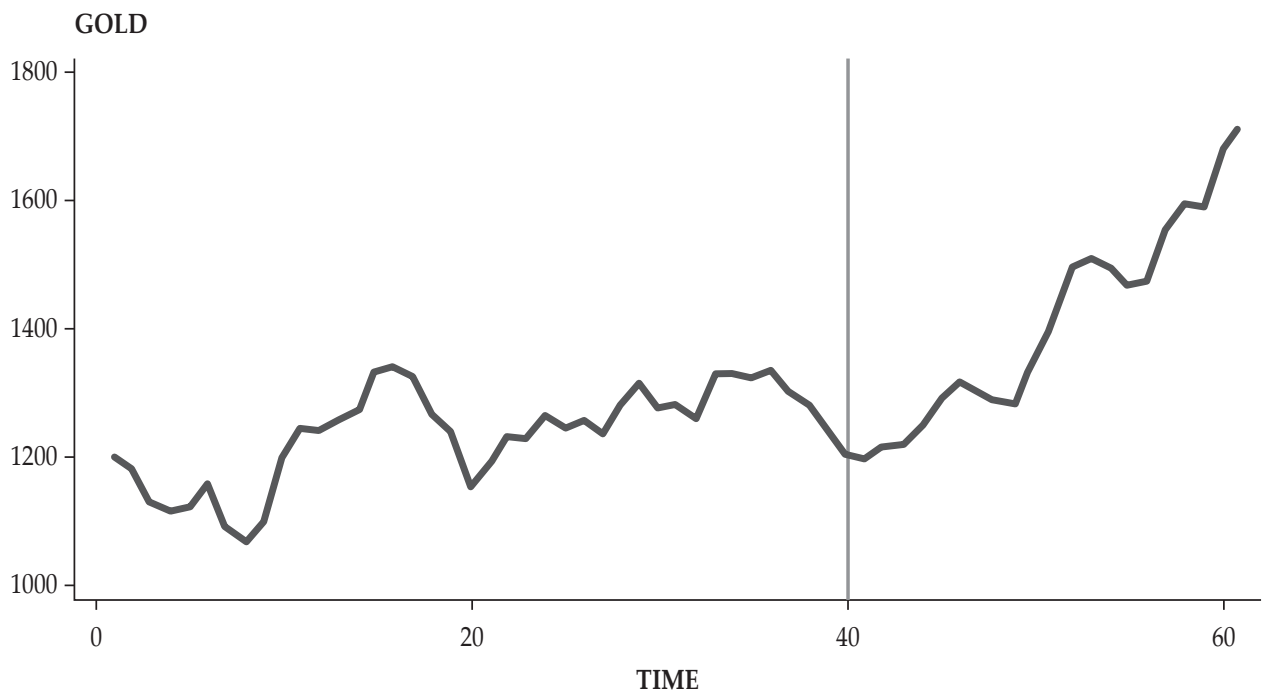

Break August 2018

Figure 10. Gold Prices

From the logit model, our analysis concluded that the consumer confidence index of Islamic finance products was affected by changes in the Jakarta Islamic index, Islamic banking capital and gold price fluctuations, with negative relationships. In this case, we assumed that the consumers of Islamic finance products, especially Islamic financial investors, have avoided gharar conditions 
during the pandemic. This is illustrated in Figures 7 and 8, which show that the Islamic money market rate and Jakarta Islamic index have continued to fall. A major issue in both Islamic and conventional finance is whether the shocks of the volatilities in asset returns are substitutes for or complement in terms of taking risk. Generally, the characteristics of Islamic stocks are different to those of conventional stocks, in that the former entail lower leverage and smaller sized firms.

Table 10.

LPM and Probit Logit Robustness Standard Error Model 2 Probability of Consumer Confidence Index Fluctuations - Conventional Financial Sector

\begin{tabular}{lccc}
\hline $\begin{array}{l}\text { Dependent variable } \\
\begin{array}{l}\text { Probability of consumer confidence } \\
\text { index fluctuations }\end{array}\end{array}$ & LPM & Logit Model & Probit Model \\
\hline Independent variables & & & \\
\hline MMR & 0.0127565 & 1.678248 & 0.8981802 \\
ET & $-1.26 \mathrm{e}-06^{* *}$ & $-9.35 \mathrm{e}-06$ & $-5.61 \mathrm{e}-06$ \\
CSPI & $-0.0005942^{* * *}$ & $-0.0124021^{* * *}$ & $-0.0068007^{* * *}$ \\
CAR & 0.0835806 & -0.5932337 & -0.381977 \\
Pandemic dummy & 0.1122157 & 3.091916 & 1.641816 \\
SBI & 0.0228493 & -0.52208577 & -0.3895556 \\
-cons & 2.37256 & 80.38675 & 46.36734 \\
Number of observations & 61 & 61 & 61 \\
Wald chi2 & 79.76 & 24.11 & 33.91 \\
Prob> Chi2 & 0.0000 & 0.0005 & 0.0000 \\
Pseudo R-squared & 0.7752 & 0.8859 & 0.8875 \\
Log likelihood & - & -4.7798343 & -4.7103093 \\
Predicted & - & $96.72 \%$ & $96.72 \%$ \\
Sensitivity & - & $96.30 \%$ & $96.30 \%$ \\
Specificity & - & $97.06 \%$ & $97.06 \%$ \\
\hline
\end{tabular}

Note: ${ }^{*}{ }^{* *},{ }^{* * *}$ denote statistical significance at the levels of $0.10,0.05,0.01$ respectively. LPM uses Prob> F and R-squared

Furthermore, analysis was made of the consumer confidence index in the conventional financial sector. Based on the logistic regression robustness standard error in model 2, it can be concluded that the Indonesian composite stock index or IHSG fluctuations have had a dominant effect on changing consumer confidence in conventional financial markets. Grima and Merello (2020) argue that consumers' decisions are not usually based on analysis of the financial statements of companies, but are consciously driven by capital markets trends.

However, conventional financial sector consumer expectations are not statistically affected by pandemic conditions. We assume that this is because of the speculative action of conventional investors in taking risks and opportunities in the stock market during the pandemic. Shariah prohibition in the conventional context does not apply. Chen (2011) argues that consumer confidence has asymmetric effects on stock returns. Reduced confidence pushes the stock market into bear 
territory. Market pessimism has a great impact on stock returns during bear markets. A lack of consumer confidence leads to a higher probability of switching to a bear market regime.

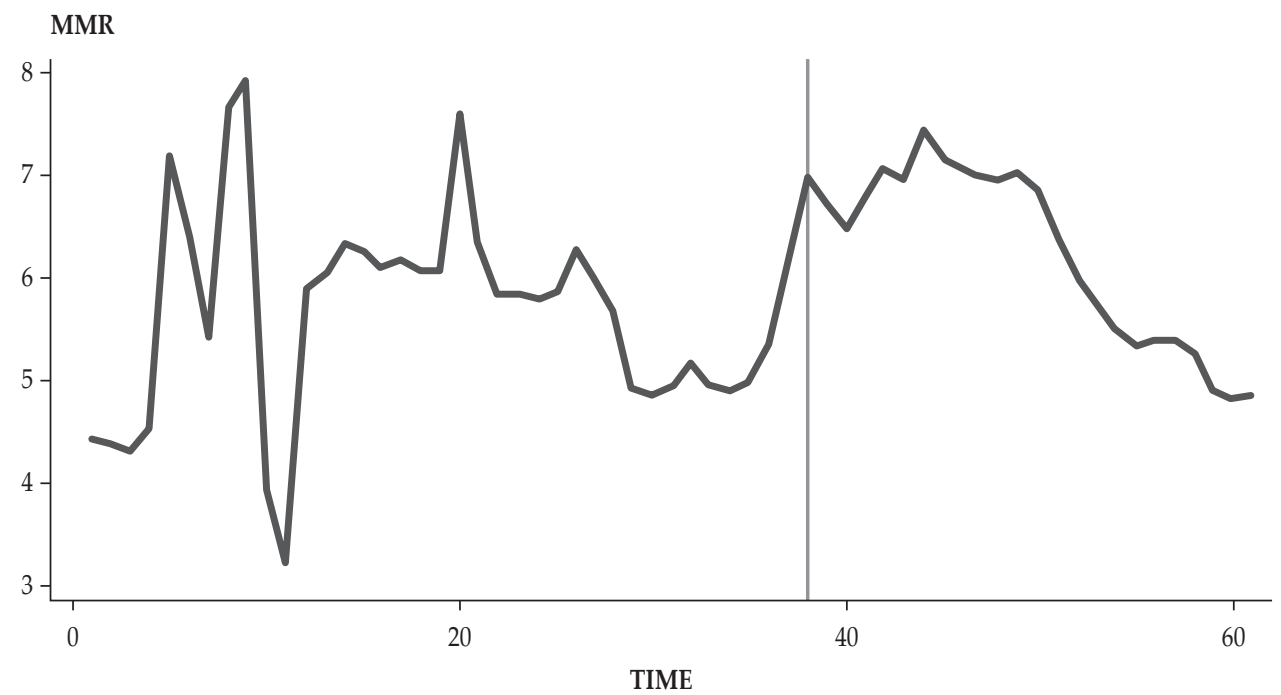

MMR Break June 2018

Figure 11. Money Market OR Index

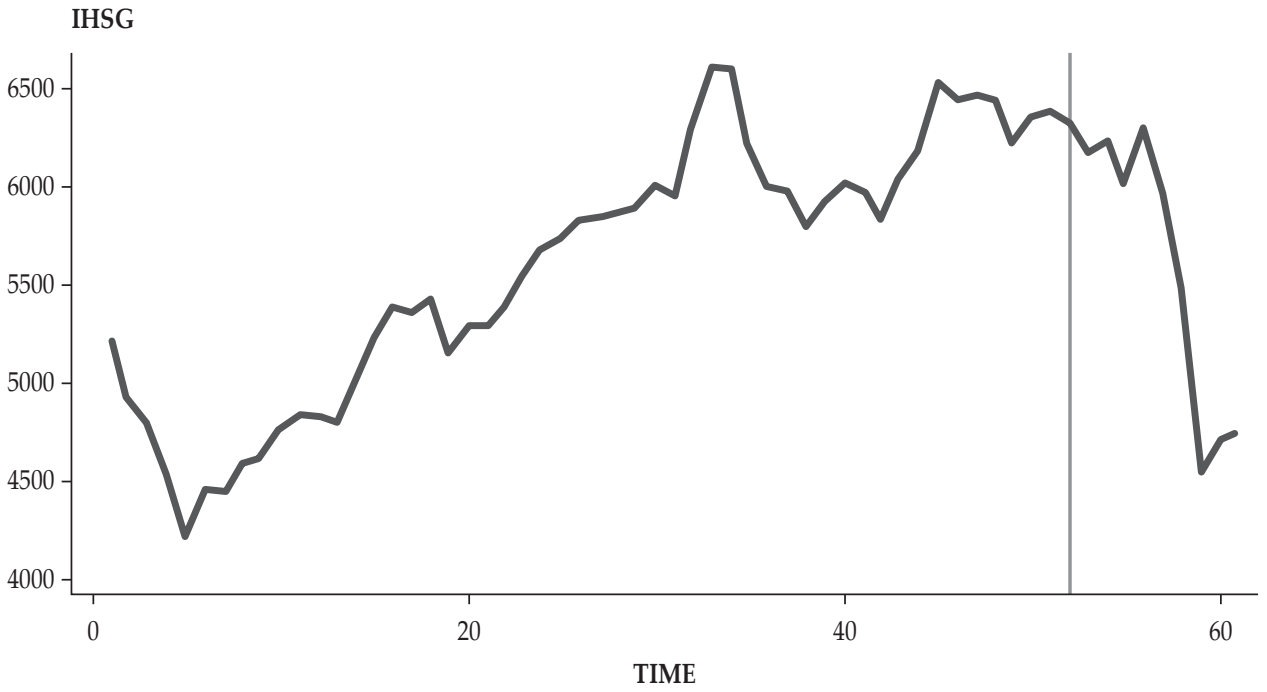

IHSG Break August 2019

Figure 12. Indonesian Composite Stock 


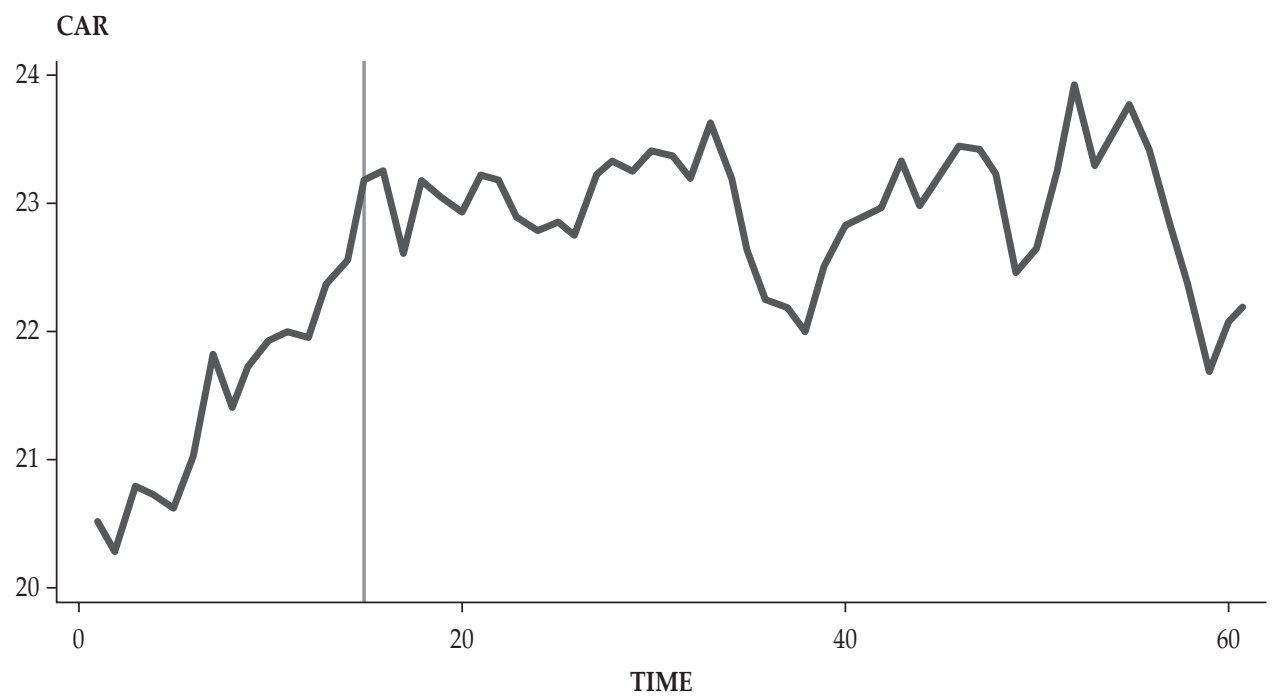

Break July 2016

Figure 13. Conventional Bank-CAR

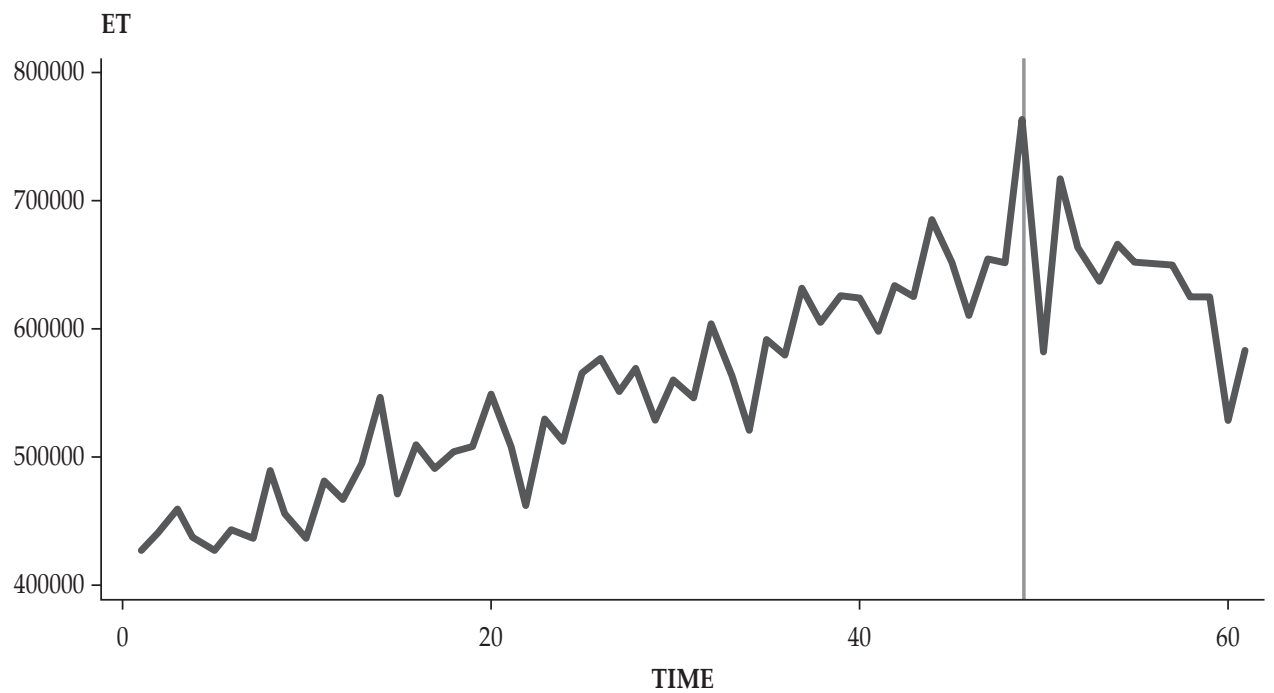

Break May 2019

Figure 14. Electronic Transactions

Many studies have investigated the relationship between the stock market and the consumer confidence index (Tobin, 1969; Bernanke et al., 1999; Poterba, 2000). The relationship can be explored from two perspectives. Some authors have found that stock market fluctuation contribute to changes in economic conditions; stock prices are influenced by investor sentiment. Other studies have investigated the opposite causal relationship between stock prices and the consumer confidence 
index. The evolution of stock prices changes the consumer confidence index through the wealth effect (Bathia \& Bredin, 2013; Fisher \& Statman, 2003). Research conducted by Jansen and Nahuis (2003) found that the stock market confidence relationship is driven by expectations about economy-wide conditions, rather than personal finances.

Based on the structural break analysis, the Islamic money market overnight rate experienced a sudden change in September 2018, while the money market overnight rate variable experienced an earlier break, in June 2018. This results in the analysis of model 1 predicting that the Islamic money market has a negative effect, while the money market rate has a positive effect, on the probability of changes in the consumer confidence index. This means that an increase in the Islamic money market rate will result in an increase in consumer expectations of the Indonesian economy in the following 6 months during the pandemic, related to the wheels of the business world, income levels and availability of employment opportunities in the community.

\section{CONCLUSION AND RECOMENDATIONS}

\subsection{Conclusion}

The Covid-19 pandemic has affected the world in various ways (Mendez \& Alias, 2020). Our study concludes that the farmer exchange rate in ten provinces in Indonesia has been affected by the pandemic conditions. There is a difference in the rate before and after the breakout of the pandemic internationally, being higher after the event occurred. This have happened due to the subsidies provided by the government to the poor during the pandemic. One of the Indonesian government's policies to increase consumption is to provide subsidies to low-income people. The fluctuations in the farmer exchange rates are also indicated by changes in regional gross domestic product and economic growth at the national level. The rate has a direct and indirect effect on farmer poverty (Setiyowati et al. 2018). Our analysis of the ten provinces concluded that the highest rate was in Riau, and the lowest in Nangro Aceh Darussalam.

The consumer confidence index of Islamic finance products was affected by changes in the Jakarta Islamic index, Islamic banking capital and gold price fluctuations, with negative relationships. We assume this was because the consumers of Islamic finance products, especially Islamic financial investors, have avoided major gharar conditions during the pandemic. The Indonesia composite stock index or IHSG fluctuations have a dominant effect on changing consumer confidence in conventional financial markets. However, conventional financial sector consumer confidence has not been statistically affected by the pandemic conditions. This could be the case because of the speculative action by conventional investors in taking risks and opportunities in the stock market during the pandemic. Shariah prohibition in the conventional context does not apply.

\subsection{Recommendations}

Consumer confidence reflects public confidence in future economic prospects, which will drive the business cycle. In mobilising public confidence and increasing 
public consumption in pandemic conditions, it is highly recommended that practitioners and regulators increase consumption by providing subsidies for low-income people. We also recommend that Bank Indonesia and other regulators briefly watch investors' speculative action in the pandemic situation, as it will influence the Indonesian stock market. Islamic consumer confidence is influenced by the Islamic money market rate, Jakarta Islamic index and the level of Islamic banking capital, while conventional consumer confidence is influenced by IHSG fluctuations. The implications of our research will be useful for policymakers in forecasting economic developments, stock market regulation, and the banking sector. In order to manage Islamic consumer confidence, Islamic banking capital, the Jakarta Islamic index and the Islamic money market rate should be stabilised. We recommend that regulators manage the variables mentioned earlier to create financial institution regulatory standards, since Islamic and conventional financial sectors have different characteristics. We suggest that future researchers obtain more comparative data and conduct a detailed study of the 34 provinces in Indonesia, clustering the effects of the pandemic in each of these.

\section{REFERENCES}

Acemoglu, D., \& Scott, A. (1994). Consumer confidence and rational expectations: Are agents' beliefs consistent with the theory? The Economic Journal, 104 (422), 1-19. https://doi.org/10.2307/2234671.

Bathia, D., \& Bredin., D. (2013). An examination of investor sentiment effect on G7 stock market returns. The European Journal of Finance, 19(9), 909-937. https:// doi.org/10.1080/1351847X.2011.636834.

Bernanke, B. S., Gertler, M., \& Gilchrist, S. (1999). The financial accelerator in a quantitative business cycle framework. Handbook of Macroeconomics, 1(Part C), 1341-1393. https://doi.org/10.1016/S1574-0048(99)10034-X.

Bock, D.E., Eastman, J.K., \& McKay, B. (2014). The impact of economic perceptions on status consumption: An exploratory study of the moderating role of education. Journal of Consumer Marketing, 31(2), 111-117. https://doi. org/10.1108/JCM-10-2013-0725.

Carroll, C. D, Fuhrer, J. C, \& Wilcox, D. W. (1994). Does consumer sentiment forecast household spending? If so, why? The American Economic Review, 84(5), 1397-1408. https://www.jstor.org/stable/2117779.

Chen, S-S. (2011). Lack of consumer confidence and stock returns. Journal of Empirical Finance, 18(2), 225-236.

Dees, S., \& Brinca, P. S. (2013). Consumer confidence as a predictor of consumption spending: Evidence for the United States and the Euro area. International Economics, 134(August 2013), 1-14. https://doi.org/10.1016/j.inteco.2013.05.001.

Fan, C. S, \& Wong, P. (1998). Does consumer sentiment forecast household spending ?: The Hong Kong case. Economics Letters, 58(1), 77-84.

Ferrer, E., Salaber, J., \& Zalewska, A. (2016). Consumer confidence indices and stock markets' meltdowns. The European Journal of Finance, 22(3), 195-220.

Fisher, K.L., \& Statman., M. (2003). Consumer confidence and stock returns. The Journal of Portfolio Management, 30(1), 115-127. 
Friedman, M. (1957). The permanent income hypothesis. In Friedman (Eds.), A Theory of the Consumption Function (pp. 20-37). New Jersey: Princeton University Press. http://www.nber.org/books/frie57-1.

Grima, A. Z., \& Merello, P. (2020). Consumer confidence: Causality links with subjective and objective information sources. Technological Forecasting and Social Change, 150(January 2020), 119760.

Gujarati, D. (2015). Econometrics by example. USA: Palgrave Macmillan.

Hall, R. E. (1978). Stochastic implications of the life cycle-permanent income hypothesis: Theory and evidence. Journal of Political Economy, 86(6), 971-987.

Hasan, Z. (2005). Treatment of consumption in Islamic economics: An appraisal. JKAU: Islamic Economics, 18(2), 29-46.

Haugh, H. (2005). A research agenda for social entrepreneurship. Social Enterprise Journal, 1(1), 1-12.

Hoffman, C., \& Fieseler, C. (2012). Investor relations beyond financials: Nonfinancial factors and capital market image building. Corporate Communications: An International Journal, 17(2), 138-155.

Howrey, E. P. (2001). The predictive power of the index of consumer sentiment. Brookings Papers on Economic Activity, 32(2001-1), 175-216.

Iyke, B. N, \& Ho, S.-Y. (2019). Consumption and exchange rate uncertainty: Evidence from selected Asian Countries. The World Economy, 43(9), 2437-2462.

Jansen, W. J, \& Nahuis, N. J. (2003). The stock market and consumer confidence: European Evidence. Economics Letters, 79(1), 89-98.

Juhro, S. M. (2015). The role of the central bank in promoting sustainable growth: Perspectives on the implementation of flexible ITF in Indonesia. Afro Eurasian Studies Journal, 4(1), 23-61.

Juhro, S. M, \& Iyke, B. N. (2019). Monetary policy and financial conditions in Indonesia. Bulletin of Monetary Economics and Banking, 21(3), 283-302.

Juhro, S. M, \& Iyke, B. N. (2019). Consumer confidence and consumption expenditure in Indonesia. Economic Modelling, 89(July 2020), 367-377.

Kahf, M. (1978). The Islamic economy: Analytical study of the functioning of the Islamic economic system. Plainfield, Indiana:The Muslim Students Association of The United States and Canada.

Khan, M.F. (1984). Macro consumption function in an Islamic framework. Journal of Research in Islamic Economics, 1(2), 3-25.

Li, H., Guo, Y., \& Park, S. Y. (2017). Asymmetric relationship between investors' sentiment and stock returns: Evidence from a quantile non-causality test. International Review of Finance, 17(4), 617-626.

Mannan, M.A. (1986). Islamic economics: Theory and practices. Cambridge: Hodder and Stoughton.

Mendez, C. E., \& Arias, J. (2020). Covid-19 effect on herding behaviour in European capital markets. ScienceDirect. Finance Reserach Letters. Elsevier Public Health Emergency Collection. DOI: 10.1016/j.frl.2020.101787

Metwally, M. M. (1997). Economic consequences of appliying Islamic principles in muslim societies. International Journal of Social Economics, 24(7/8/9), 941-957.

Mobarek, A., Mollah, S., \& Keasey, K. (2014). A cross-country analysis of herd behavior in Europe. Journal of International Financial Markets, Institutions and Money, 32(C), 107-127. 
Morlino, L., \& Quaranta, M. (2016). What is the impact of the economic crisis on democracy? Evidence from Europe. International Political Science Review, (May 2016). Sage Journals. https://doi.org/10.1177/0192512116639747.

Muthuramu, P., \& Maheswari, T.U. (2019). Tests for structural breaks in time series analysis: A review of recent development. Shanlax International Journal of Economics, 7(4), 66-79.

Nadenicheck, J. (2007). Consumer confidence and economic stagnation in Japan. Japan and The World Economy, 19(3), 338-346.

Naqvi, S. N. H. (1997). The dimensions of an Islamic economic model. Islamic Economic Studies, 4(2), 1-23.

Paradiso, A., Kumar, S., \& Margani, P. (2014). Are Italian consumer confidence adjustments asymmetric? A macroeconomic and psychological motives approach. Journal of Economic Psychology, 43(August 2014), 48-63.

Poterba, J. M. (2000). Stock market wealth and consumption. Journal of Economic Perspectives, 14(2), 99-118.

Salhin, A., Sherif, M., \& Jones, E., (2016). Managerial sentiment, consumer confidence and sector returns. International Review of Financial Analysis, 47(October 2016), 24-38.

Setiyowati, I. L., Sasongko, \& Noor, I. (2018). Farmer exchange rate and agricultural conversion analysis to agricultural sector poverty in Indonesia. Jurnal Ekonomi dan Studi Pembangunan, 10(1), 35-43.

Siddiqi, M. N. (2005). Teaching Islamic economics. Jeddah, Saudi Arabia: Scientific Publishing Centre, King Abdul Aziz University.

Sorić, P., (2018). Consumer confidence as a GDP determinant in New EU member states: A view from a time-varying perspective. Empirica, 45(2), 261-282.

Syekh, S. (2013). Peran nilai tukar petani dan nilai tukar komoditas dalam upaya peningkatan kesejahteraan petani padi di Provinsi Jambi. Jurnal Bina Praja: Journal of Home Affairs Governance, 5(4), 253-260.

Tan, L., Chiang, T. C, Mason, J. R, \& Nelling, E. (2008). Herding behavior in Chinese stock markets: An examination of A and B shares. Pacific-Basin Finance Journal, 16(1-2), 61-77.

Tobin, J. (1969). A general equilibrium approach to monetary theory. Journal of Money, Credit and Banking, 1(1), 15-29. The Ohio State University Press. JSTOR. Zaman, A. (1997). Towards foundation of an Islamic theory of consumer behavior. Essays in Islamic Economic Analysis (pp. 37-51). Kuala Lumpur. 